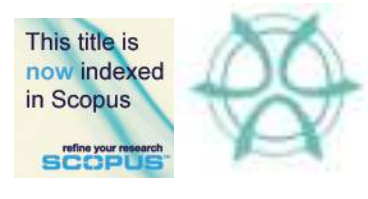

PLANNING MALAYSIA:

Journal of the Malaysian Institute of Planners

SPECIAL ISSUE IV (2016), Page 383 - 394

\title{
MEASURING THE DIMENSIONS AND ATTRIBUTES OF LIVEABILITY OF LOW-INCOME HOUSING COMMUNITIES IN NIGERIA
}

\author{
Sule Abass Iyanda ${ }^{1} \&$ Mohammad Abdul Mohit ${ }^{2}$ \\ ${ }^{1,2}$ Kulliyyah of Architecture \& Environmental Design \\ INTERNATIONAL ISLAMIC UNIVERSITY MALAYSIA
}

\begin{abstract}
Housing is a basic human need and its liveability transcends beyond the perimeter of the housing unit. The quality of the living environment is important for an individual's wellbeing. The factors that contribute to the inhabitants' satisfaction in a living environment are essential inputs in monitoring the success of housing policies of the government. This paper measured the dimensions and attributes of the living environment of the public lowincome housing estates in Minna, Niger State. A questionnaire was administered to 400 household heads in the three selected housing estates based on stratified random sampling. 366 questionnaires were returned and the data were analyzed with descriptive statistics and factor analysis. Results showed that residents are satisfied with housing unit and economic vitality, but dissatisfied with neighbourhood facilities, and social interaction was lacking among the residents. Also, residents are apprehensive of their safety. This study recommends an immediate improvement of neighbourhood facilities in these housing estates.
\end{abstract}

Keyword: Liveability, Low-income housing, Factor analysis, Niger State

\section{INTRODUCTION}

Housing remains one of the three most essential needs of man (UN-Habitat, 2006) and it can be described as an integral part of a human frame which should respond to the need of its inhabitants. It encompasses all the auxiliary services and living environment facilities, which are necessary to human well-being. The right to a safe, secure, healthy and inexpensive adequate housing was enshrined in the Habitat Agenda (UN-Habitat, 2001). This global call for human settlement and shelter encouraged the government of nations to intensify efforts to provide housing for their citizens in particular for the lowincome populace (Makinde, 2013). Prior to this, Nigeria governments at various times have introduced different housing policies to solve housing deficit problem. Thus, evidences from various studies, show that Nigerians are still under-housed (Nse, 2012; Ademiluyi and Raji, 2008; Makinde, 2013; Ibem and Aduwo, 2012; Aribigbola, 2008). Nevertheless, both federal government and the state governments have continued building housing units for various levels of income groups (low, middle and high-income) in their respective territory. After the independence in 1960, the governments' commitment towards low-income housing is dated back to the First National 
Sule Abass Iyanda \& Mohammad Abdul Mohit

Measuring the Dimensions and Attributes of Liveability of Low-Income Housing Communities in Nigeria

Development Plan (1962-1968). However, there is a lack of mechanism to gauge the success of the government public housing policies or programmes. A successful housing provision does not only depend on merely provision of housing units, but also on the other factors that affects the needs of residents. The failure of many housing projects may be attributed to the lack of knowledge on what determines the liveability of a living environment.

In the recent times, liveability concept has attracted much attention from different disciplines. However, liveability as a concept is an urban planning concept that connotes the ability of a living environment to support human well-being or simply quality of life. Though, the concept of liveability has been said to be difficult to work with due to the imprecise definition (Balsas, 2004; Heylen, 2006; Leby and Hashim, 2010). On a global scale, center for liveable cities Singapore (2011) defined liveability as that city with a good planning that provides a vibrant, attractive and secure environment for the people to live their life, work and play. It encompasses good governance, gives a competitive economy, high quality of life and environmental sustainability. Also, Economic Intelligence Unit (2012) sees liveability as an assessment of which locations around the world provide the best or the worst living conditions. On the other hand, Mercer quality of life survey (2011) examined liveability dimensions which include, among others; political and social environment, education, etc. On global cases, indicators such as country political stability, international relations with other countries and the presence of international schools were given considerations. However, on a community/residential environment level that is the focus of this study, liveability has been made operational. In such studies liveability dimensions include; social, physical, functional and safety elements (Leby and Hashim, 2010). Furthermore, a study from Netherland by Heylen (2006) looked at the dimensions of housing/dwelling quality, physical environment quality, social environment quality and Safety of the neighbourhood. Moreover, Omuta (1988) from Nigeria examined neighbourhood liveability through the dimensions of employment, housing, amenity, education, nuisance and socioeconomic. With these few studies discussed, it is obvious that various definitions and applications as found in the literature centered on the human well-being or the satisfaction of the needs of the people (Balsas, 2004). It is against this background, the liveability dimensions and attributes of public low-income housing estates of Niger State is being measured to monitor the success of the state government housing policy.

\section{AIM AND OBJECTIVES}

The overall aim is to measure the dimensions and attributes of the liveability of public low-income housing with respect to the respondents' level of satisfaction with their living conditions. Hence, the objectives are as follows:

i. To test the reliability and validity of measurement structure of assessing liveability with respect to respondents' satisfaction with their living environment.

ii. To determine the degree to which the various dimensions and attributes explain liveability

iii. To determine the residents' level of satisfaction with their housing environments 


\section{METHODOLOGY}

This study adopts quantitative research approach. The conduct of household surveys was based on stratified random sampling purposely to select various homes in the three public low-income housing estates selected. 400 housing units were surveyed out of 1000 housing units in three different locations (Krejcie \& Morgan, 1970). However, 366 respondents (household heads) returned their questionnaires which represents $91.5 \%$ response and used for the analysis. The questionnaire items measurement was based on 5-point Likert scale (Marques et al., 2015; Mohit and Hannan, 2012). The questionnaire instrument had six sections; the first section was on the socioeconomic characteristics of the respondents, the other five sections focused on the dimensions of liveability that includes economic vitality, housing unit characteristics, social environment, neighbourhood facilities and safety environment. Prior to the conduct of the household survey in the study area, a pre-test of the questionnaire instrument was conducted, and the feedback incorporated into the final version of the questionnaire.

\section{VARIABLE DESCRIPTIONS}

From the extant literature; quite numbers of variables were identified to have been used to determine the liveability based on the interest and focus of the study. The variables of socioeconomic characteristics are commonly variables and this forms the first category of the variable used in this study, and these are; age, gender, marital status, household size, indigene-ship, education, employment status, and number of working class, monthly income, length of stay and tenure status. The other category of variables is related to the assessment of liveability of the living environment as found in many studies and summarized in the Table1 below;

Table 1: Dimensions associated with liveability assessment in different studies

\begin{tabular}{|c|c|c|}
\hline Authors & Liveability dimensions & Focus \\
\hline Omuta (1988) & $\begin{array}{l}\text { Employment, Housing, Amenity, } \\
\text { Education, Nuisance and Socioeconomic }\end{array}$ & $\begin{array}{l}\text { Study on the quality of urban } \\
\text { life and liveability }\end{array}$ \\
\hline Balsas (2004) & $\begin{array}{l}\text { Safe, Clean, Beautiful, Economically } \\
\text { vital, Affordable to a diverse population, } \\
\text { Efficiently administered, Functional } \\
\text { infrastructure, Ample parks, Effect public } \\
\text { transportation, Interesting cultural } \\
\text { activities and Sense of community }\end{array}$ & $\begin{array}{l}\text { The study explored urban } \\
\text { center liveability }\end{array}$ \\
\hline Chaudhury (2005) & $\begin{array}{l}\text { Consumer goods, Utility services, } \\
\text { Housing affordability, Social Security } \\
\text { and Environmental Conditions }\end{array}$ & $\begin{array}{l}\text { Comparative study on City } \\
\text { liveability in Bangladesh }\end{array}$ \\
\hline Heylen (2006) & $\begin{array}{l}\text { Dwelling unit, Physical Environment, } \\
\text { Social Environment and Safety }\end{array}$ & Social Housing Liveability \\
\hline Betanzo (2009) & $\begin{array}{l}\text { Connectivity, Accessibility, Mixed use } \\
\text { and Density }\end{array}$ & $\begin{array}{l}\text { Exploring city density } \\
\text { liveability relationships }\end{array}$ \\
\hline Leby and Hashim (2010) & $\begin{array}{l}\text { Social, Physical, Functional and Safety } \\
\text { dimensions }\end{array}$ & $\begin{array}{l}\text { Neighbourhood liveability } \\
\text { study in Malaysia }\end{array}$ \\
\hline Asiyanbola et al. (2012) & $\begin{array}{l}\text { Neighbourhood Facilities; Road Quality, } \\
\text { Garbage Collection, Public Transport, } \\
\text { State of Cleanliness, Street Light, State } \\
\text { of Security, Crime Level, Water Supply, } \\
\text { Shops, Interpersonal relationship, School } \\
\text { Quality, Drainage System, Power Supply } \\
\text { and General condition }\end{array}$ & $\begin{array}{l}\text { Comparative study of two } \\
\text { neighbourhoods liveability in } \\
\text { Ogun state, Nigeria }\end{array}$ \\
\hline
\end{tabular}


Sule Abass Iyanda \& Mohammad Abdul Mohit

Measuring the Dimensions and Attributes of Liveability of Low-Income Housing Communities in Nigeria

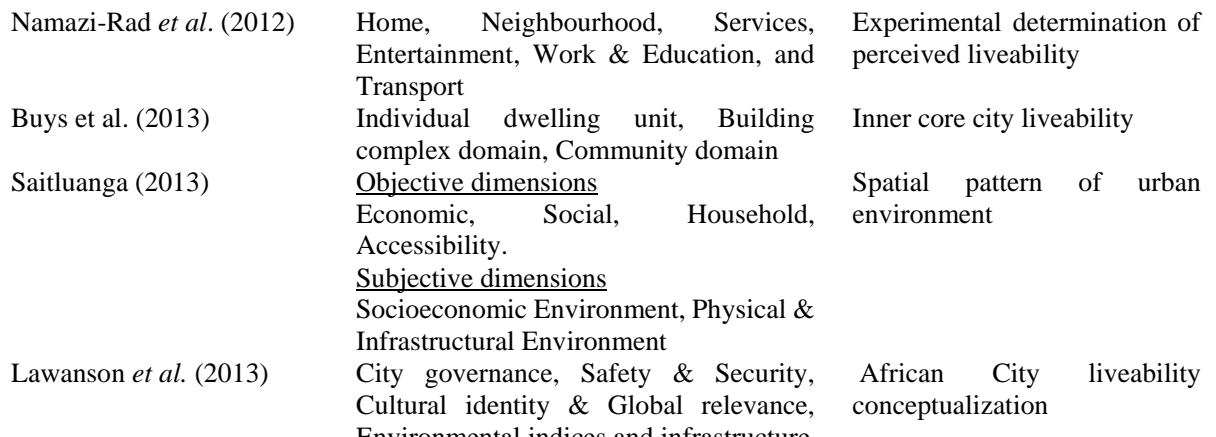

\section{DATA ANALYSIS}

\section{Descriptive statistics}

The descriptive statistical analysis was conducted, and it produced the proportions and percentages for the eleven variables of socioeconomic characteristics of the respondents. Also, obtained are the average satisfaction scores for each construct of measures of liveability for all items of the constructs. This helps in identifying the level of satisfaction with the specific individual item. All these analyses were carried out in the statistical package for social sciences (SPSS) version 22 with analysis of moment structure (AMOS) version 22.

\section{Item Reliability Test}

The construct items were tested for reliability and found to have reliable Cronbach's alpha reading above 0.70 except safety-environment and social interaction constructs which is less than 0.70. In the case of safety-environment, the seven items achieve 0.50 which is less than a tolerable limit value of 0.60 (Creswell, 2011). However, Pallant (2007) opined that Cronbach's alpha above 0.70 is preferable, and when the researcher obtained less than 0.70 , the items measuring the construct should be scrutinized to know which item or items are not measuring what ought to be measured and may be considered for recoding in case of the negatively worded item or removed. It is against this background that four items from the construct "safety-environment" were removed, leaving three items in the construct with Cronbach's alpha 0.916. On the other hand, the construct "social interaction" violates the model assumption reliability having recorded negative values, and the construct was removed from the initially hypothesized model. The exact alpha values for each of the variables are as shown in Table 2 below;

Table 2: Variables internal consistency reliability Cronbach's alpha values

\begin{tabular}{cccc}
\hline Variables & No of Items & No of Items deleted & $\begin{array}{c}\text { Cronbach's } \\
\text { Alpha }\end{array}$ \\
\hline Housing unit characteristics & 13 Items & None & 0.932 \\
Economic vitality & 6 Items & None & 0.866 \\
Neighbourhood facilities & 11 Items & None & 0.715 \\
Safety environment & 7 Items & 4 items & 0.916 \\
Social interaction & 3 Items & All & -0.947 \\
\hline
\end{tabular}




\section{Exploratory factor analysis}

The exploratory factor analysis with the principal component method was conducted purposely to identify the key dimensions of liveability as evaluated by the respondents. This dealt with multi-collinearity issues that would have arisen due to intercorrelations among the indicators used in measuring the housing estates liveability in the survey. From the extant literature, correlation matrix should be inspected to check for the singularity of items or indicators. Each indicator should have at least 0.2 percent correlation with another indicator. This relationship shows that they are both contributing in measuring a particular latent construct. An item or indicator without such attributes should be deleted (Andy, 2009; Eugenie et al., 2014).

\section{RESULTS AND DISCUSSIONS}

\section{The socioeconomic characteristics of the respondents}

The results of the descriptive statistical analysis showed that the majority (79\%) of the participants are men. The majority $(60.6 \%)$ is at the age of 31-50years; the estimated average age is 43 years and close to $94 \%$ obtained higher education. Nearly $70 \%$ are gainfully employed in both government and private sectors. $85 \%$ of the respondents are married, and $62 \%$ had a household size of five persons and above. The estimated average household size stood at 7 . And $58 \%$ of these families have only two persons working. However, 63\% earned close to N100, 000.00 (USD500) per month, 32\% about N200, 000.00 (USD1000) monthly and the remaining 5\% earned above N200, 000.00 monthly. Furthermore, $76 \%$ represents owners' occupied, and $24 \%$ are renters. Also, on the length of stay $73 \%$ indicates less than ten years while others have lived there between ten years and thirty years. Also, $75 \%$ are from the state, and the other $25 \%$ are from other states of Nigeria. Based on the above, the participants in the survey could be said to have enough knowledge of their neighbourhood environment and, therefore, the data emanated from them could be regarded as reliable.

\section{Overall satisfaction level with liveability dimensions}

The pattern of responses from the residents of the three housing estates seems similar. The mean overall satisfaction for housing unit characteristics, neighbourhood facilities, safety-environment, economic vitality and social interaction are as shown in Table 3 . The residents in M.I. Wushishi estate, Bosso estate and Tunga low-cost were satisfied with their housing unit characteristics with average scores of 3.10, 3.54 and 3.58 respectively. A similar finding on dwelling unit was reported in the study of private low-cost housing in Malaysia by Salleh (2008). Also, the residents' level of satisfaction with economic vitality shows contentment with average scores of 3.18, 3.37 and 3.71 in M.I. Wushishi, Bosso estate and Tunga low-cost respectively. However, in all the three housing estates the residents expressed low satisfaction on the neighbourhood facilities and social interaction. This finding corroborates the findings of the study of the low-cost residential environment in Malaysia by Ismail et al. (2015). Similarly, residents of M.I. Wushishi and Bosso estates expressed low satisfaction for the safety environment with average scores of 2.82 and 2.93 respectively, whereas, residents in Tunga low-cost were satisfied with safety in their neighbourhood with a mean score of 3.16 . 
Sule Abass Iyanda \& Mohammad Abdul Mohit

Measuring the Dimensions and Attributes of Liveability of Low-Income Housing Communities in Nigeria

Table 3: Overall satisfaction with liveability dimensions

\begin{tabular}{|c|c|c|c|c|}
\hline $\begin{array}{l}\text { Liveability } \\
\text { dimensions }\end{array}$ & M.I. Wushishi & Bosso Estate & $\begin{array}{l}\text { Tunga Low- } \\
\text { Cost }\end{array}$ & Overall Mean \\
\hline $\begin{array}{l}\text { Housing unit } \\
\text { characteristics }\end{array}$ & 3.10 & 3.54 & 3.58 & 3.40 \\
\hline $\begin{array}{l}\text { Neighbourhood } \\
\text { facilities }\end{array}$ & 2.62 & 2.60 & 2.91 & 2.71 \\
\hline Safety environment & 2.82 & 2.93 & 3.16 & 2.97 \\
\hline Economic vitality & 3.18 & 3.37 & 3.71 & 3.41 \\
\hline Social interaction & 2.65 & 2.70 & 2.57 & 2.64 \\
\hline
\end{tabular}

\section{Satisfaction with housing units}

Evidence from Table 4 shows residents of M.I. Wushishi estate raised concern about the road network, parking lots, cleanliness of the estate and overall housing condition. The average satisfaction scores range between 1.91 and 2.88 suggesting their dissatisfaction of these indicators of housing unit liveability. Meanwhile, residents of Bosso estate were only dissatisfied with road network (mean value of 2.98). However, residents in Tunga low-cost are satisfied with all housing unit characteristics. It can be inferred that housing units in Bosso estate and Tunga low-cost appeared more acceptable than the M.I. Wushishi housing units. In these two housing estates, the mean values obtained are higher than the mean values obtained in the responses of the residents of M.I. Wushishi estate.

Table 4: Satisfaction with housing units

\begin{tabular}{cccc}
\hline Housing unit characteristics & M.I. Wushishi & Bosso Estate & $\begin{array}{l}\text { Tunga Low } \\
\text { Cost }\end{array}$ \\
\hline House ventilation & & 3.83 & 3.79 \\
House size & 3.58 & 3.77 & 3.64 \\
Living area size & 3.47 & 3.66 & 3.69 \\
Dining area size & 3.46 & 3.67 & 3.27 \\
Size of bedroom & 3.20 & 3.72 & 3.62 \\
Size of kitchen & 3.44 & 3.59 & 3.52 \\
No of Bathrooms & 3.16 & 3.50 & 3.43 \\
No of toilets & 3.14 & 3.44 & 3.42 \\
Affordability & 3.16 & 3.71 & 3.69 \\
Road network & 3.53 & 2.98 & 3.58 \\
Parking lots & 1.91 & 3.17 & 3.47 \\
Cleanliness of the estate & 2.54 & 3.53 & 3.75 \\
Overall housing condition & 2.91 & 3.51 & 3.72 \\
\hline
\end{tabular}




\section{Satisfaction with neighbourhood facilities}

It is evident from overall mean neighbourhood facilities satisfaction scores of 2.62, 2.60 and 2.91 (Table 3); that the respondents were generally dissatisfied with neighbourhood facilities in the three housing estates investigated. This contrasts the findings of the study of residents' satisfaction with public housing in Abuja by Ukoha and Beamish (1997).

However, Table 5 shows the average score values for each of the attributes used in measuring neighbourhood facilities satisfaction as rated by all the respondents. It is evident that the respondents in the three housing estates investigated were satisfied with children education services, healthcare services and garbage collection in their neighbourhoods. The satisfactions mean values ranged between 3.26 and 3.89 (Table 5). These findings provide support for previous study by Salleh (2008) indicating that residents of private low-cost housing of Penang and Terengganu in Malaysia were satisfied with neighbourhood facilities such as schools, health center and garbage disposal. On the other hand, the residents of Bosso estate and Tunga low-cost were satisfied with public transport services with mean scores of 3.31 and 3.73 respectively but, M.I. Wushishi housing estate residents' were not satisfied with public transport services as the mean score of 2.74 was obtained. The mean scores obtained for water supply revealed that only residents of Tunga low-cost were satisfied with a mean score of 3.06 while residents in M.I. Wushishi and Bosso estates were dissatisfied with water supply with average scores of 2.55 and 2.51 respectively. On the electricity supply, Bosso estate seems to be at the disadvantage with 2.57 mean scores compared with mean scores of 3.26 and 3.04 for M.I. Wushishi estate and Tunga low-cost respectively. However, it is apparent from Table 5 that respondents were dissatisfied with attributes related to the availability of open/green space, shopping centers \& community hall, the nature of road and drainage system condition. It can be inferred from the results that respondents were only satisfied with about $45 \%$ of the total neighbourhood facilities attributes investigated. In these findings, it can see that it is consistent with the previous study's findings showing lack of access to basic neighbourhood facilities in public housing estates in Lagos and Ogun States, Nigeria (Ilesanmi, 2012; Ibem and Aduwo, 2013).

Table 5: Satisfaction with neighbourhood facilities

\begin{tabular}{cccc}
\hline Neighbourhood facilities & M.I. Wushishi & Bosso Estate & Tunga Low Cost \\
\hline Children educational services & 3.51 & 3.72 & 3.85 \\
Health care services & 3.62 & 3.29 & 3.76 \\
Garbage collection & 3.26 & 3.47 & 3.89 \\
Water supply & 2.55 & 2.51 & 3.06 \\
Electricity supply & 3.26 & 2.57 & 3.04 \\
Public transport & 2.74 & 3.31 & 3.73 \\
Open/green space & 1.80 & 1.69 & 1.66 \\
Shopping centers & 1.83 & 1.50 & 1.64 \\
Community Hall & 1.92 & 1.98 & 1.99 \\
Nature of road & 1.95 & 2.31 & 2.99 \\
Drainage system & 2.41 & 2.21 & 2.40 \\
\hline
\end{tabular}

\section{Satisfaction with safety}

Table 6 shows the mean satisfaction scores for all safety attributes. The respondents were satisfied with only three out of seven safety attributes measured. They are safety from 
Sule Abass Iyanda \& Mohammad Abdul Mohit

Measuring the Dimensions and Attributes of Liveability of Low-Income Housing Communities in Nigeria

crime, safety from accident and property safety. These three attributes indicate mean satisfaction scores above 3.00 out of possible 5.00 points. Evidently, respondents are not satisfied with police protection and street lighting. Also, it is evident that there is a lack of provision in terms of firefighter (fire brigade) and vigilante protection in the neighbourhoods.

Table 6: Satisfaction with safety environment

\begin{tabular}{cccc}
\hline Safety environment & M.I. Wushishi & Bosso Estate & Tunga Low Cost \\
\hline Safety from crime & 3.13 & 3.87 & 3.95 \\
Safety from accident & 3.63 & 3.92 & 4.06 \\
Property safety & 3.30 & 3.94 & 4.03 \\
Vigilante protection & 2.82 & 2.38 & 2.53 \\
Police protection & 2.65 & 2.28 & 2.90 \\
Fire brigade & 1.65 & 1.83 & 2.75 \\
Street light & 2.60 & 2.30 & 1.92 \\
\hline
\end{tabular}

\section{Satisfaction with economic vitality}

It is evident that the respondents are satisfied with their economic vitality/liveliness with mean values ranging from 3.10 to 3.90 in all the three housing estates. This means that respondents are satisfied with what they are earning and not affected either by paying a housing loan or being a renter. However, residents of M.I. Wushishi were less satisfied with their access to public transport (Table 7).

Table 7: satisfaction with economic vitality

\begin{tabular}{cccc}
\hline Economic vitality & M.I. Wushishi & Bosso Estate & Tunga Low Cost \\
\hline Household monthly income & 3.14 & 3.49 & 3.82 \\
Daily cost of transportation & 3.10 & 3.39 & 3.83 \\
Rental value & 3.47 & 3.90 & 3.71 \\
Loan repayment & 3.63 & 3.88 & 3.65 \\
Access to public transport & 2.98 & 3.31 & 3.82 \\
Standard of living & 3.10 & 3.12 & 3.31 \\
\hline
\end{tabular}

\section{Satisfaction with social interaction}

Table 8 indicates that there is good communication between neighbours in all the three housing estates investigated. However, there is a lack of voluntary activities in all housing estates selected. The average scores of the responses indicates 1.58 (M.I. Wushishi), 1.86 (Bosso estate) and 1.55 (Tunga low-cost). As a result, there is the lack of participation.

Table 8: Satisfaction with social interaction

\begin{tabular}{cccc}
\hline Social interaction & M.I. Wushishi & Bosso Estate & Tunga Low Cost \\
& & & \\
\hline Communication between neighbours & 3.86 & 3.82 & 4.03 \\
Voluntary activities & 1.58 & 1.86 & 1.55 \\
Level of participation & 2.36 & 1.89 & 1.87 \\
\hline
\end{tabular}




\section{Exploratory factor analysis}

Based on the inspection of the initial correlation matrix, two items of housing units are highly correlated with the value of 0.928 , then one was deleted. Following this was the Kaiser-Meyer-Okin (KMO) and Bartlett's Test for adequacy of sample size for factor analysis, the result shows that the sample is adequate. This KMO is suggested to be above 0.5 and for Bartlett's significant level should be less than 0.05 . Both criteria were met as the value obtained for KMO is 0.917 and for Bartlett significant level, the value is 0.000 . The result shows no singularity problem, although the determinant of multicollinearity value of less than 0.00001 was not met, but it is not severe since the correlation values of the exogenous variables are less than 0.9 (Eugenie et al., 2014). Also, based on communalities items with a value less than 0.5 were dropped. However, the total variance explained based on initial Eigenvalues of 1 with four factors extracted, gives to a cumulative of $66.868 \%$ (Table 9).

Table 9: Total variance explained from factor analysis

\begin{tabular}{|c|c|c|c|c|c|c|c|c|c|}
\hline \multirow[b]{2}{*}{$\begin{array}{l}\text { Componen } \\
\mathrm{t}\end{array}$} & & itial Eige & values & $\begin{array}{l}\text { I Variar } \\
\text { Extrac }\end{array}$ & $\begin{array}{l}\text { ce Explai } \\
\text { ion Sums } \\
\text { Loadin } \\
\end{array}$ & $\begin{array}{l}\text { ed } \\
\text { of Squared } \\
\text { s }\end{array}$ & \multicolumn{3}{|c|}{$\begin{array}{c}\text { Rotation Sums of Squared } \\
\text { Loadings }\end{array}$} \\
\hline & Total & $\begin{array}{c}\% \text { of } \\
\text { Varianc } \\
\mathrm{e}\end{array}$ & $\begin{array}{c}\text { Cumulativ } \\
\text { e \% }\end{array}$ & Total & $\begin{array}{c}\% \text { of } \\
\text { Varianc } \\
\mathrm{e}\end{array}$ & $\begin{array}{c}\text { Cumulativ } \\
\text { e \% }\end{array}$ & Total & $\begin{array}{c}\% \text { of } \\
\text { Varianc } \\
\mathrm{e}\end{array}$ & $\begin{array}{c}\text { Cumulativ } \\
\text { e } \%\end{array}$ \\
\hline 1 & $\begin{array}{r}10.22 \\
9\end{array}$ & 42.622 & 42.622 & $\begin{array}{r}10.22 \\
9\end{array}$ & 42.622 & 42.622 & $\begin{array}{r}5.71 \\
6\end{array}$ & 23.816 & 23.816 \\
\hline 2 & 2.711 & 11.296 & 53.918 & 2.711 & 11.296 & 53.918 & $\begin{array}{r}4.36 \\
4\end{array}$ & 18.183 & 41.999 \\
\hline 3 & 1.756 & 7.315 & 61.233 & 1.756 & 7.315 & 61.233 & $\begin{array}{r}4.25 \\
3\end{array}$ & 17.721 & 59.720 \\
\hline 4 & 1.352 & 5.634 & 66.868 & 1.352 & 5.634 & 66.868 & $\begin{array}{r}1.71 \\
5 \\
\end{array}$ & 7.147 & 66.868 \\
\hline
\end{tabular}

Extraction Method: Principal Component Analysis.

\section{CONCLUSION}

This study investigated and measured the extent to which residents in the three public low-income housing estates in Minna, Niger State, Nigeria perceived the liveability of their housing estates. The liveability dimensions and attributes of public low-income housing neighbourhoods were established through the extant literature. From the data analysis, four constructs of liveability dimensions and attributes were found to satisfy both internal reliabilities and construct validity (Table 2). Also, finding showed that the four factors extracted with an Eigenvalues of 1 explained about $67 \%$ variance of liveability dimensions of public low-income housing estates investigated, this could be said to be substantial (Table 9).

On the whole, the residents in all the three housing estates were satisfied with housing unit characteristics and economic vitality. Although there are a few attributes of these dimensions that the residents were dissatisfied with, such as the road network in both M.I. Wushishi and Bosso estates, others attributes in M.I.Wushishi estate is parking lots, cleanliness of the estate and overall housing conditions.

Also, findings showed that residents in the three housing estates were unsatisfied with the provision/supply of water, open/green space, shopping centers, community hall, nature of roads and drainage system in the housing estates. Despite this, residents were 
Sule Abass Iyanda \& Mohammad Abdul Mohit

Measuring the Dimensions and Attributes of Liveability of Low-Income Housing Communities in Nigeria

satisfied with few neighbourhood facilities which includes; children educational services, healthcare services, garbage collection and electricity supply with the exception of Bosso estate where residents were dissatisfied with electricity supply. Also, respondents were satisfied with public transport in both Bosso estate and Tunga low-cost while residents of M.I.Wushishi estate felt dissatisfied.

On the safety dimensions, respondents in all the three housing estates investigated affirmed their safety from crime, accident, and they are confident of their property safety. However, they express low satisfaction on police protection, vigilante protection, fire brigade availability and street lighting. These are all important in securing the neighbourhoods against any attack.

Moreover, there is the lack of social interactions among the residents of these three housing estates investigated; however there is good communication between neighbours. This lack of social interactions may not be unconnected with the lack of neighbourhood facilities like open space/ recreation ground.

Conclusively, with evidence from the data analyzed, government efforts to provide shelter for the low-income groups in the state has been successful in terms of housing unit and economic livelihood (economic vitality). The indicator of this success is reflected in the level of respondents' satisfaction where $68 \%$ of all respondents were satisfied with both housing unit and economic livelihood. However, the respondents' demographic data analysis showed that average household size is seven (7). The policy implication of the above is that while the government continues the provision of affordable housing, it is recommended to increase the development of three bedrooms and above rather than the current policy of developing more of two bedrooms.

In this study, neighbourhood facilities have been identified as inadequate in all the three housing estates. The inadequacy of neighbourhood facilities affects the quality of life negatively and, as a result, the residents were dissatisfied. This study, therefore, recommends proper monitoring by the public housing development agency in the state to ensure that neighbourhood facilities of high quality are delivered along with housing units. And where the neighbourhood facilities are delivered, there is a need for collaboration between government agency in charge of its maintenance and the residents in that neighbourhood to fashion out maintenance strategies. Besides, the current situation in these housing estates needs to be improved, and the least in the liveability profile is M.I. Wushishi estate, therefore, the upgrading/improvement of the neighbourhood facilities should commence there.

Also, security is one of the keys to liveability of the living environment; therefore, the current police divisions in housing estates should be made functional. They should be more on surveillance (patrol) to prevent crimes of any sort. Further, street lights contribute to safety in the neighborhoods, especially in the night. Provision of street lights in all the three housing estates investigated is recommended. It is also important to have firefighter district units for easy access in a case of a fire incident.

As discussed above, the low level of social interaction among the dwellers of these housing estates may not be unconnected with the lack of outdoor space for informal contact among residents. This study, therefore, recommends that outdoor spaces such as open space, children's playground, and shopping centers should always be planned with such large estates. This will encourage social interaction, and it will bring about 
community association that will help to create safety in the housing estates, and community participation in matters affecting their living environment.

\section{ACKNOWLEDGMENTS}

An earlier version of this paper was presented at the $13^{\text {th }}$ International Congress of Asian Planning Schools Association (APSA) Universiti Teknologi Malaysia, (UTM), Johor Bahru, Malaysia, 12-14 August, 2015.

\section{REFERENCES}

Ademiluyi, I. A. and Raji, B. A. (2008), Public and Private Developers as Agents in Urban Housing Delivery in Sub-Saharan Africa: the Situation in Lagos State

Aribigbola, A. (2008), Housing policy formulation in developing countries: Evidences of Programme Implementation from Akure, Ondo State Nigeria. Journal of Human Ecology, 23(2), 125-134.

Asiyanbola, R., Raji, B. and Shaibu, G. (2012) 'Urban liveability in Nigeria- A pilot study of Ago-Iwoye and Ijebu-Igbo in Ogun State', Journal of Environmental Science and Engineering Pp 1203-1213

Andy, F. (2009) 'Discovering statistics using SPSS', Third Edition, SAGE Publication Ltd Betanzo, D. M. (2009) 'Exploring Density Liveability Relationships', The Built \& Human Environment Review, Volume 2, Special Issue 1, 2009

Chaudhury, A. H. (2005) 'Urban Liveability, Decentralisation and Development: A Comparative Study on Dhaka and Khulna Cities', URP Discipline, Khulna University

Creswell, J. W. (2011) 'Educational research: planning, conducting, and evaluating quantitative and qualitative Research', 4th Edition

Economist Intelligence unit (2012) 'A Summary of the Liveability Ranking and Overview' www.eiu.com

Eugenie, E. C., Ahmad, N. and Sabri, B. A. (2014) 'A Comparison between Individual Confirmatory Factor Analysis and Pooled Confirmatory Factor Analysis: An Analysis of Library Service Quality, a Case Study at a Public University in Terengganu', International Journal of Engineering Science and Innovative Technology (IJESIT) Volume 3, Issue 1

Heylen, K. (2006) 'Liveability in social housing: three case-studies in Flanders. Residential Environments and People', ENHR Conference July 2006. Ljubljana, Slovenia.

Ibem, E.O. and Aduwo, E.B. (2012), Public-Private Partnerships (PPPs) in Urban Housing in Nigeria: Evidence from Ogun State. International Journal of Architecture and Urban Development, Vol.2, No2

Ibem, E.O. and Aduwo, E.B. (2013) 'Assessment of Residential Satisfaction in Public Housing in Ogun State, Nigeria', Habitat International, 40:163-175

Ilesanmi, A.O. (2012) 'Housing, Neighbourhood Quality and Quality Of Life in Public Housing in Lagos, Nigeria', International Journal for Housing Science, Vol.36, No.4 Pp.231-240

Ismail, F., Jabar, I. L., Janipha, N. A. I. and Razali, R. (2015) 'Measuring the Quality of Life in Low Cost Residential Environment', In Procedia - Social and Behavioral Sciences 168 Pp270 - 279 
Sule Abass Iyanda \& Mohammad Abdul Mohit

Measuring the Dimensions and Attributes of Liveability of Low-Income Housing Communities in Nigeria

Krejcie, R.V. \& Morgan, D.W. (1970) 'Determining sample size for research activities', Educational \& Psychological Measurement', 30, 607-610.

Lawanson, T., Salau, T. and Yadua, O. (2013) 'Conceptualizing the Liveable African City’, Journal of Construction Project Management and Innovation Vol. 3 (1): 573-588

Leby, J. L. and Hashim, A. H. (2010) 'Liveability Dimensions and Attributes: Their Relative Importance in the Eyes of Neighbourhood Residents', Journal of Construction in Developing Countries, Vol.15(1), 67-91

Makinde, O.O. (2013), Housing Delivery System: Need and Demand. Environment Development and Sustainable, Open access at Springerlink.com [Accessed on $6 / 11 / 13]$

Marques, D., Pinheiro, M. R., Matos, A. P., and Marques, C. (2015) 'Confirmatory Factor Analysis of the QRI Father's Version in a Portuguese sample of adolescents', In Procedia - Social and Behavioral Sciences 165 Pp 267 - 274

Mercer Human Resource Consulting (2011) 'Quality-of-Living Reports 2011' http://www.mercerhr.com

Mohit, M. A. and Hannan, M. H. E. (2012) 'A Study of Crime Potentials in Taman Melati Terrace Housing in Kuala Lumpur: Issues and Challenges', In Procedia - Social and Behavioral Sciences 42 Pp $271-283$

Namazi-Rad, M., Perez, P., Berryman, M. and Lamy, F. (2012) 'An experimental determination of perceived liveability in Sydney', ACSPRI Conferences, RC33 Eighth International Conference on Social Science Methodology Pp. 1-13.

Nse, U. (2012), Exploring the enabling approach to housing through the Abuja Mass Housing Scheme. Master thesis submitted to Massachusetts Institute of Technology

Omuta, G.E.D. (1988) 'The Quality of Urban Life and The Perception of Liveability: A Case Study of Neighbourhoods in Benin City, Nigeria', Social Indicators Research 20 Pp417-440

Pallant, J. (2007) 'SPSS Survival Manual A Step by Step Guide to Data Analysis using SPSS for Windows third edition', Open University Press, McGraw-Hill Education, McGraw-Hill House

Saitluanga, B. L. (2013) 'Spatial Pattern of Urban Liveability in Himalayan Region: A Case of Aizawl City, India'

Salleh, A. G. (2008) 'Neighbourhood factors in private low-cost housing in Malaysia ', Habitat International 32 Pp485-493

Ukoha, O.M. and Beamish, J.O. (1997) 'Assessment of residents' satisfaction with public housing in Abuja, Nigeria', HABITAT INTERNATIONAL, Vol.21 No 4 Pp445-460

UN-Habitat (2001), The right to adequate housing: A major commitment of the Habitat Agenda. Office of the High Commissioner for Human Rights, May, 2001

UN-Habitat (2006), Regulatory Framework and Strategic Urban Planning and Management;

Conference Paper on Housing and Urban Development, Nairobi, 3 -4 April. www.unhabitat.org. [Accessed on 29/10/08] 